\title{
Maternal and environmental influences on thermoregulation in the neonate
}

\author{
BY M. E. SYMONDS AND M. A. LOMAX \\ Department of Biochemistry and Physiology, School of Animal and Microbial Sciences, University \\ of Reading, Whiteknights, PO Box 228, Reading RG6 $2 A J$
}

In precocious mammalian species such as man and sheep which do not benefit from the protection of a higher local environmental temperature due to huddling in a nest, the ability to alter metabolic rate in response to changes in ambient temperature at birth is a prerequisite for survival. A principal tissue involved in metabolic adaptation to the extra-uterine environment in both precocious and altricial species such as rodents is brown adipose tissue (BAT), which has the ability to rapidly generate large amounts of heat and also converts thyroxine to triiodothyronine $\left(\mathrm{T}_{3}\right)$, the dominant hormone regulating metabolic rate. Heat generation in BAT is a result of the electron transport chain becoming uncoupled from ATP synthesis, an effect mediated by a unique mitochondrial protein, uncoupling protein or thermogenin (see Cannon \& Nedergaard, 1985).

In both infants and lambs BAT comprises $1-2 \%$ of birth weight (Merklin, 1974; Alexander \& Bell, 1975) and is found predominantly in the axillary and perirenal region in infants and perirenal-abdominal area in sheep (Alexander, 1978). Infants, however, are rarely exposed to a cold environment and are completely dependent on non-shivering thermogenesis, whilst newborn lambs can generate appreciable amounts of heat from shivering as well as non-shivering thermogenesis (see Mellor \& Cockburn, 1986). This contrasts with neonatal pigs which do not possess BAT and are entirely dependent on shivering thermogenesis to maintain heat production during cold exposure. In both infants and lambs, therefore, the amount and activity of BAT is likely to have a significant effect on thermoregulation. Over the first weeks of life in sheep (Gemmel et al. 1972) or months of life in man (Naeye, 1974) BAT is gradually replaced by white adipose tissue and as a result shivering rather than non-shivering thermogenesis is the principal response to cold exposure. An apparent failure to utilize BAT during neonatal development is associated with unexpected death (Naeye, 1974; Symonds et al. 1989) and may be an important factor contributing to the annual lamb mortality of 1-4 million in the British sheep industry (Slee, 1979).

\section{FETAL BAT DEVELOPMENT}

The thermogenic capacity of BAT, as measured from GDP-binding to thermogenin in mitochondrial preparations or the presence of mRNA for thermogenin, appears to remain low throughout gestation (Casteilla et al. 1987, 1989) and then peak at birth. Growth and development of BAT in the fetus can be divided into three distinct phases: (1) tissue growth as a result of hyperplasia and hypertrophy, (2) differentiation and the ability to generate $T_{3}$, (3) expression of thermogenin during late pregnancy and birth.

The multilocular cells which are characteristic of BAT first appear at mid-gestation in both human (Moragas \& Toran, 1983), and sheep fetuses (Gemmel \& Alexander, 1978). In the ovine fetus there then follows an increase in cell volume, tissue weight (see Vernon, 1986), lipid content (Alexander, 1978) and proliferation of mitochondria (Gemmel \& Alexander, 1978) with the growth of perirenal adipose tissue being linear to 
that of the whole body up to $120 \mathrm{~d}$ of gestation in ad lib.-fed ewes. The principal substrates for fatty acid synthesis at this stage of gestation are acetate, glucose and lactate (Vernon et al. 1981), although the in vivo contribution of these lipogenic substrates has yet to be determined. Between $120 \mathrm{~d}$ of gestation and term ( $147 \mathrm{~d})$ the in vitro rates of fatty acid production from all these lipogenic substrates fall dramatically and the rate of lipid accumulation in BAT drops (Alexander, 1978) as an increasing proportion of acetate taken up by BAT is oxidized (Vernon et al. 1981). At this stage of pregnancy insulin treatment can stimulate the in vitro rate of glucose conversion to lipid in BAT (Fain et al. 1984).

Although only a small amount of BAT growth occurs in the last month of gestation in comparison with total growth of the ovine fetus, there are major morphological and enzymic changes within BAT cells which appear to be crucial with respect to the tissue's ability to generate heat. These include the development of sympathetic innervation (Gemmel \& Alexander, 1978), a rise in the activity of 5'-monodeiodinase (EC 3.8.1.4; Wu et al. 1990) which converts thyroxine to $T_{3}$ and expression of genes for thermogenin and lipoprotein lipase (EC 3.1.1.34; Casteilla et al. 1989; Giralt et al. 1990). Ovine BAT appears to contain two distinct 5'-monodeiodinases (Wu et al. 1990), a type I which has a Michaelis constant $\left(K_{m}\right)$ for $T_{4}$ and reverse $T_{3}$ in the micromolar range and type II with a $K_{m}$ in the nanomolar range. Bovine fetal BAT only possesses the type I form of $5^{\prime}$-monodeiodinase and its activity rises after $150 \mathrm{~d}$ of gestation but then falls 2-3 weeks before birth ( $270 \mathrm{~d}$ of gestation). A decrease in type II $5^{\prime}$-monodeiodinase activity has also been observed immediately before birth in fetal rat BAT (Giralt et al. 1990) but not in sheep (Wu et al. 1990). This change in activity of 5'-monodeiodinase may be regulated by the sympathetic nervous system as observed in adult rats (Silva \& Larson, 1983) with the local production of $T_{3}$ being essential for full expression of thermogenin (Bianco \& Silva, 1987).

The induction of thermogenin gene expression in bovine fetal BAT commences at approximately day 200 of gestation and is associated with maximal activity of $5^{\prime}$ monodeiodinase (Casteilla et al. 1989; Giralt et al. 1989). It is not known if this effect is mediated via an increased rate of $\mathrm{T}_{3}$ production within BAT because inhibition of 5 '-monodeiodinase activity over the last $4 \mathrm{~d}$ of pregnancy in rat pups fails to prevent the first appearance of mRNA for thermogenin (Giralt et al. 1990). Other factors present in utero may, therefore, be responsible for thermogenin gene expression towards the end of pregnancy. This could include noradrenaline which regulates the overall thermogenic activity of BAT in adult rats (Mory et al. 1984) or insulin which is necessary for BAT retention in growing mice (Geloen \& Trayhurn, 1990). Nerves are first seen in ovine fetal BAT at day 130 of gestation and their numbers increase towards term (Gemmel \& Alexander, 1978) by which stage BAT is endowed with insulin receptors. Also the observation that BAT growth, in ovine fetuses, is stimulated following fetal hypophysectomy at $112 \mathrm{~d}$ of gestation (Stevens \& Alexander, 1986) is indicative of a negative influence by the pituitary on BAT development. The possible role of the sympathetic nervous system and pancreatic or pituitary hormones on fetal BAT differentiation remains to be explored.

\section{MATERNAL MANIPULATION OF BAT DEVELOPMENT}

Maternal undernutrition of species where placental transport of fatty acids is low (i.e. sheep and rats) results in a decrease in BAT deposition, independent of effects on fetal 
growth (Alexander, 1978; Higham et al. 1984). In sheep this response is likely to be caused by significant reductions in the rate of maternal supply of both glucose and acetate to the growing fetus (Lindsay \& Ford, 1964; Leury et al. 1990). This effect can be exacerbated by a reduction in placental size (Mellor, 1983) or its ability to transport glucose (Leury et al. 1990) during maternal undernutrition. Diets low in protein, fed to pregnant rats, also decrease BAT weight and its thermogenic activity (Tyzbir, 1984).

Cold stress during late pregnancy stimulates the in vivo capacity for non-shivering thermogenesis in newborn lambs (Stott \& Slee, 1985) and BAT deposition in neonatal rats (Hyvarinin et al. 1976). Chronic cold exposure, induced by winter-shearing twin-bearing pregnant ewes approximately 8 weeks prepartum, also improves lamb survival and lamb birth weight, independent of changes in maternal feed intake (Rutter et al. 1971; Symonds et al. 1986). This increase in lamb birth weight from shorn ewes is likely to be a consequence of elevated fetal plasma concentrations of glucose and insulin (Thompson et al. 1982), since maternal glucose entry-rate and plasma concentration of glucose are increased over the final 2-4 weeks of pregnancy (Symonds et al. 1988a,b). Glucose infusion directly into the fetus during this period has a greater stimulatory effect on BAT growth compared with that of the whole body (Stevens et al. 1990). BAT sampled from lambs born from shorn ewes possesses a $40 \%$ higher thermogenic activity and these lambs exhibit an $18 \%$ increased rate of oxygen consumption (per $\mathrm{kg}$ body-weight) over the first day of life compared with those born from unshorn ewes (Symonds et al. 1991). Consequently an increase in glucose supply to the late-gestation fetus in conjunction with a rise in fetal insulin levels appears to stimulate the growth of BAT in utero (Stevens et al. 1990) and its thermogenic activity postnatally (Symonds et al. 1991).

\section{METABOLIC ADAPTATION AT BIRTH}

Premature delivery of lambs is associated with an apparent failure to generate heat via non-shivering thermogenesis (Alexander et al. 1972) similar to that observed following chemical sympathectomy of the fetus (Alexander \& Stevens, 1980). This is indicative of BAT not being functional, despite appearing normal histologically. A similar situation appears to pertain in human infants as the rise in heat production during cold exposure is lower in premature deliveries compared with term babies (Heim, 1981). Some premature infants even lose their ability to respond to moderate cold exposure over the first week of life (Hey \& Katz, 1969).

The fetus is unable to generate heat via non-shivering thermogenesis in BAT in utero, and it has been proposed that the onset of thermogenesis is limited by a placental factor because thermogenesis rises after cord-clamping (see Power, 1989). One putative candidate for this role is adenosine for which the plasma concentration falls dramatically following cord-clamping (Sawa et al. 1991). The interpretations of these experiments, however, must be made with caution because direct measurements of the thermogenic capacity of BAT were not made. There is a two-fivefold increase in the levels of mRNA for thermogenin within hours of birth in calves (Casteilla et al. 1989) and rats (Giralt et al. 1990). In rat pups this increase in thermogenin mRNA is a result of exposure to cold environment after birth and is dependent on $5^{\prime}$-monodeiodinase activity (Giralt et al. 1990). The ability of BAT to synthesize large amounts of mRNA following parturition may, therefore, be regulated by the sympathetic nervous system. 


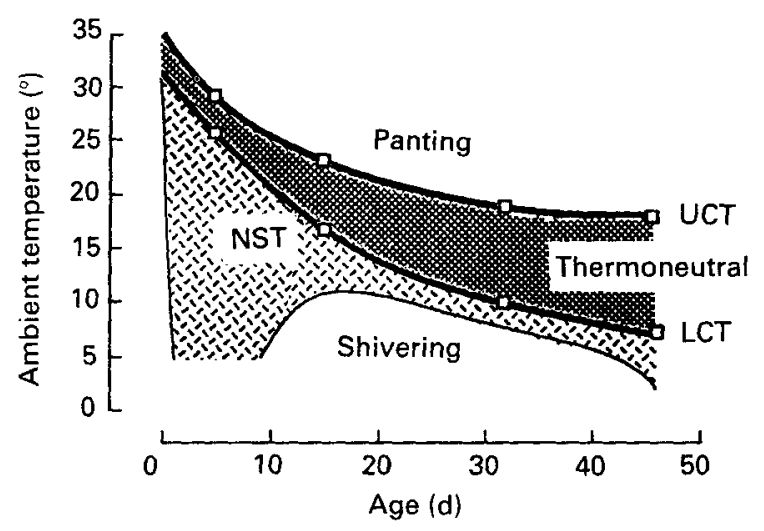

Fig. 1. Metabolic adaptation over the first $45 \mathrm{~d}$ of life in the neonatal lamb. UCT, upper critical temperature, i.e. occurrence of panting; LCT, lower critical temperature, i.e. significant rise in oxygen consumption or the ocurrence of shivering, or both; NST, non-shivering thermogenesis. Adapted from Symonds et al. (1989).

Irrespective of the adaptations to birth which initiate the onset of non-shivering thermogenesis in BAT there appears to be a gradual increase in its activity over the first days of neonatal life in human infants. The metabolic response to cold exposure or to noradrenaline infusion rises over the first few hours (Smales \& Kime, 1978) and days of life (Hill \& Rahimtulla, 1965; Karlberg et al. 1965), in both small and normal-weight infants (Hey, 1969). A gradual increase in the thermogenic activity of BAT could explain why in a newborn baby rectal temperature falls by $2^{\circ}$ following exposure to an ambient temperature of $23^{\circ}$ for $30 \mathrm{~min}$ within $1 \mathrm{~h}$ of birth, but only by $0.5^{\circ}$ by $3 \mathrm{~h}$ post partum (Rylander, 1972). It has yet to be determined how a change in activity of BAT at birth can affect the longer-term control of thermoregulation in developing infants.

\section{THERMOREGULATORY DEVELOPMENT AND ITS MANIPULATION BY THE ENVIRONMENTAL TEMPERATURE}

Over the first $45 \mathrm{~d}$ of life in the lamb there is a widening of the thermoneutral zone as the neonate adjusts to the extrauterine environment which is summarized in Fig. 1. (Symonds et al. 1989). This metabolic adaptation is associated with a decrease in the plasma concentration of $T_{3}$ but not thyroxine (Symonds et al. 1989) and occurs as BAT is converted to white adipose tissue (Gemmel et al. 1972). The rate at which BAT is depleted can be delayed by hyperthyroidism (Alexander et al. 1970) and by rearing at cold ambient temperatures in both young ruminants (Gemmel et al. 1972; Casteilla et al. 1989; Darby et al. 1992) and rat pups (Mouroux et al. 1990). The net effect of this environmental manipulation is for BAT to retain a higher thermogenic activity and delay the onset of shivering thermogenesis (see Table 1). Environmental temperature is also important in human infants because warm rearing (abdominal skin temperature maintained at $36.5^{\circ}$ ) between 1 and 3 weeks of life results in a decreased metabolic response to cold $\left(28^{\circ}\right)$, suggesting a loss of thermogenic activity in BAT (Glass et al. 1968). These responses are dependent on adequate nutrition and growth of the infant because the rate of lipid depletion in BAT is accelerated in malnourished sick infants 
Table 1. Effect of warm $\left(25^{\circ}\right)$ or cold $\left(15^{\circ}\right)$ rearing on the thermogenic capacity of brown adipose tissue (BAT) on days 7-9 of life in neonatal lambs

(Mean values with their standard errors)

\begin{tabular}{|c|c|c|c|c|c|c|c|c|c|c|c|}
\hline & \multirow{2}{*}{\multicolumn{2}{|c|}{$\begin{array}{l}\text { Perirenal } \\
\text { adipose } \\
\text { tissue wt }(\mathrm{g})\end{array}$}} & \multirow{2}{*}{\multicolumn{2}{|c|}{$\begin{array}{l}\text { Mitochondrial } \\
\text { protein }(\mathrm{mg})\end{array}$}} & \multirow{2}{*}{\multicolumn{2}{|c|}{$\begin{array}{c}\text { GDP binding } \\
\text { (pmol/mg } \\
\text { protein) }\end{array}$}} & \multicolumn{4}{|c|}{$\begin{array}{c}V_{\mathrm{O}_{2}} \\
(\mathrm{ml} / \mathrm{min} \text { per } \mathrm{kg} \mathrm{W})\end{array}$} & \multirow{3}{*}{$\begin{array}{c}\text { No. of } \\
\text { lambs } \\
\text { shivering }\end{array}$} \\
\hline & & & & & & & \multicolumn{2}{|c|}{$26^{\circ}$} & \multicolumn{2}{|c|}{$12^{\circ}$} & \\
\hline & Mean & $\mathrm{SE}$ & Mean & SE & Mean & SE & Mean & SE & Mean & $\mathrm{SE}$ & \\
\hline $\begin{array}{l}\text { Warm-reared } \\
\quad(n 8)\end{array}$ & $24 \cdot 0^{*}$ & $3 \cdot 3$ & 422 & 50 & $123^{* *}$ & 21 & $14 \cdot 4^{*}$ & 0.7 & $19 \cdot 7$ & 1.9 & 7 \\
\hline $\begin{array}{l}\text { Cold-reared } \\
\quad(n 8)\end{array}$ & $16 \cdot 5$ & $2 \cdot 3$ & 441 & 78 & 189 & 31 & $16 \cdot 8$ & $1 \cdot 0$ & $20 \cdot 4$ & 1.0 & 3 \\
\hline
\end{tabular}

$V_{\mathrm{O}_{2}}$, oxygen consumption; $\mathrm{W}$, body-weight.

Mean values were significantly different from those for cold-reared animals: ${ }^{*} P<0.05 ;{ }^{*} P<0 \cdot 01$.

born prematurely at 34 weeks of gestational age and nursed at room temperature of $22-27^{\circ}$ in comparison with a group born after 30 weeks of gestation and nursed in an incubator at $34-35^{\circ}$ (Heim et al. 1968).

During neonatal development there is an important link between $\mathrm{T}_{3}$ and non-shivering thermogenesis via BAT, because lambs of normal birth weight with a low plasma concentration of $T_{3}(0 \cdot 34-1.73 \mathrm{nM})$ respond to acute cold exposure $\left(2-3 \mathrm{~h}\right.$ at $\left.5-10^{\circ}\right)$ by shivering whilst other lambs with high plasma levels of $T_{3}(2.06-3.69 \mathrm{nM})$ exhibit non-shivering thermogenesis (Symonds et al. 1989). Lambs with low $T_{3}$ levels can become hypothermic and subsequently die, an effect which is more pronounced in lambs born prematurely (Cabello, 1983). An impairment in the thermogenic capacity of BAT in conjunction with an inability to generate $T_{3}$ could be linked to the absence of a single major gene which enables BAT to respond to noradrenaline despite BAT being normal in its histological appearance (Slee \& Simpson, 1991). The ability of BAT to produce $\mathrm{T}_{3}$ is essential in maintaining its normal thermogenic response (Bianco \& Silva, 1987) and at the same time BAT can contribute $30-60 \%$ of total $\mathrm{T}_{3}$ production in cold-exposed rats (Fernandez et al. 1987). This is more than equal to the contribution of peripheral tissues to whole-body production rate of $\mathrm{T}_{3}$ in neonatal lambs (Klein et al. 1980) which includes that of the liver (Polk et al. 1986). Successful metabolic adaptation by the neonate following birth, therefore, appears to be linked to normal BAT function in conjunction with the maintenance of elevated $\mathrm{T}_{3}$ levels.

The function of BAT in neonatal thermoregulation may be implicated in the control of breathing. Over the period in which BAT is replaced by white adipose tissue, minimal metabolic rate decreases in conjunction with a fall in breathing frequency in the lamb (Andrews et al. 1991a). Exposure of infants and lambs to warm ambient conditions close to the upper limit of thermoneutrality can cause irregular breathing and prolonged apnoeas (Adams et al. 1964; Daily et al. 1969; Andrews et al. 1991b). Impaired BAT activity and exposure to warm ambient temperatures in conjunction with a high degree of thermal insulation may explain why the latter environmental conditions are associated with sudden infant death syndrome (SIDS; Fleming et al. 1990). This contrasts with the 
observation that BAT depletion is significantly delayed in SIDS victims (Naeye, 1974). It is not known if this is caused by either a failure of BAT to respond to thermogenic stimulae as recorded in neonatal lambs (Slee \& Simpson, 1991) or of an increased stimulation of BAT activity in association with chronic hypoxaemia (Naeye, 1980).

In conclusion, the evidence cited clearly shows that BAT plays a critical role in neonatal thermoregulation in infants, ruminants and rodents. Research into mechanisms regulating fetal and neonatal BAT development in these species is likely to provide opportunities for improving neonatal survival and viability, despite the diverse conditions in which they are reared.

The authors thank the Wellcome Trust, AFRC, MRC and MAFF for their support.

\section{REFERENCES}

Adams, F. H., Tetsuro, F., Spears, R. \& Hodgman, J. (1964). Temperature regulation in premature infants. Pediatrics 33, 487-495.

Alexander, G. (1978). Quantitative development of adipose tissue in foetal sheep. Australian Journal of Biological Sciences 31, 489-503.

Alexander, G. \& Bell, A. W. (1975). Quantity and calculated oxygen consumption during summit metabolism of brown adipose tissue in newborn lambs. Biology of the Neonate 26, 214-220.

Alexander, G., Bell, A. W. \& Williams, D. (1970). Metabolic response of lambs to cold: Effects of prolonged treatment with thyroxine and of acclimation to low temperatures. Biology of the Neonate 15, 198-210.

Alexander, G. \& Stevens, D. (1980). Sympathetic innervation and the development of structure and function of brown adipose tissue: studies on lambs chemically sympathectomized in utero with 6-hydroxydopamine. Journal of Developmental Physiology 2, 119-137.

Alexander, G., Thorburn, G., Nicol, D. \& Bell, A. W. (1972). Survival, growth and the metabolic response to cold in prematurely delivered lambs. Biology of the Neonate 20, 1-8.

Andrews, D. C., Symonds, M. E. \& Johnson, P. (1991a). Thermoregulation and the control of breathing during N-REM sleep in the lamb. Journal of Developmental Physiology 16, 27-36.

Andrews, D. C., Symonds, M. E. \& Johnson, P. (1991b). The interaction of the upper airway and thermometabolism on respiratory rhythm during N-REM sleep in the developing lamb. Journal of Developmental Physiology 16, 37-43.

Bianco, A. C. \& Silva, J. E. (1987). Optimal response of key enzymes and uncoupling protein to cold in BAT depends on local $T_{3}$ generation. American Journal of Physiology 253, E255-E263.

Cabello, G. (1983). Endocrine reactivity $\left(\mathrm{T}_{3}, \mathrm{~T}_{4}\right.$ and cortisol) during cold exposure in pre-term and full-term lambs. Biology of the Neonate 44, 224-233.

Cannon, B. \& Nedergaard, J. (1985). The biochemistry of an inefficient tissue: Brown adipose tissue. Essays in Biochemistry 20, 110-164.

Casteilla, L., Champigny, O., Bouilland, F., Robelin, J. \& Riquier, D. (1989). Sequential changes in the expression of mitochondrial protein mRNA during the development of brown adipose tissue in bovine and ovine species. Biochemical Journal 257, 665-671.

Casteilla, L., Forest, C., Robelin, J., Riquier, P., Lombet, A. \& Ailhand, G. (1987). Characterisation of mitochondrial-uncoupling protein in bovine fetus and newborn calf. American Journal of Physiology 252, E627-E636.

Daily, W. J. R., Klaus, M., Belton, H. \& Meyer, P. (1969). Apnea in premature infants: Monitoring, incidence, heart rate changes, and an effect of environmental temperature. Pediatrics 43, 510-518.

Darby, C. J., Clarke, L., Lomax, M. A. \& Symonds, M. E. (1992). Effect of rearing neonatal lambs in a cold and warm environment on thermogenesis during slow wave sleep. Proceedings of the Nutrition Society (In the Press).

Fain, J. N., Mohell, N., Wallace, M. A. \& Mills, I. (1984). Metabolic effects of $\beta, \alpha_{1}$ and $\alpha_{2}$ adrenoreceptor activation on brown adipocytes isolated from the perirenal adipose tissue of fetal lambs. Metabolism 33, 289-294.

Fernandez, J. A., Mampel, T., Villarroya, F. \& Iglesias, R. (1987). Direct assessment of brown adipose tissue as a site of systemic triiodothyronine production in the rat. Biochemical Journal 243, 281-284. 
Fleming, P. J., Gilbert, R., Azaz, Y., Berry, P. J., Rudd, P. T., Stewart, A. \& Hall, E. (1990). Interaction between bedding and sleeping position in the sudden infant death syndrome. British Medical Journal 301, 85-89.

Geloen, A. \& Trayhurn, P. (1990). Regulation of the level of uncoupling protein in brown adipose tissue by insulin. American Journal of Physiology 258, R418-R424.

Gemmel, R. T. \& Alexander, G. (1978). Ultrastructural development of adipose tissue in foetal sheep. Australian Journal of Biological Sciences 31, 505-515.

Gemmel, R. T., Bell, A. W. \& Alexander, G. (1972). Morphology of adipose cells in lambs at birth and during subsequent transition of brown to white adipose tissue in warm and cold conditions. American Journal of Anatomy 133, 143-164.

Giralt, M., Casteilla, L., Vinas, O., Mampel, T., Iglesias, R., Robelin, J. \& Villarroya, F. (1989). Iodothyronine 5 '-deiodinase activity as an early event of prenatal brown fat differentiation in bovine development. Biochemical Journal 259, 555-559.

Giralt, M., Martin, J., Iglesias, R., Vinas, O., Villarroya, F. \& Mampel, T. (1990). Ontogeny and perinatal modulation of gene expression in rat brown adipose tissue. European Journal of Biochemistry 193, $297-302$.

Glass, L., Silverman, W. A. \& Sinclair, J. C. (1968). Effect of thermal environment on cold resistance and growth of small infants after the first week of life. Pediatrics 41, 1033-1046.

Heim, T. (1981). Energy requirements of thermoregulatory heat productioni in the newly born. In Physiological and Biochemical Basis for Perinatal Medicine. Samuel Z, Levine Conference, pp. 158-174 [M. Monset-Couchard and A. Minkowski, editors]. Basel: Karger.

Heim, T., Kellermayer, M. \& Dani, M. (1968). Thermal conditions and the mobilization of lipids from brown and white adipose tissue in the human neonate. Acta Paediatrica Academiae Scientiarum Hungaricae 9 , $109-120$.

Hey, E. N. (1969). The relation between environmental temperature and oxygen consumption in the new-born baby. Journal of Physiology 200, 589-603.

Hey, E. N. \& Katz, G. (1969). Temporary loss of a metabolic response to cold stress in infants of low birthweight. Archives of Disease in Childhood 44, 323-330.

Higham, F. C. , Pillay, D. \& Bailey, E. (1984). The effect of maternal diet on maternal and fetal hepatic and brown adipose-tissue lipogenesis and blood and tissue metabolites. Journal of Developmental Physiology 6, 153-158.

Hill, J. R. \& Rahimtulla, K. A. (1965). Heat balance and the metabolic rate of new-born babies in relation to environmental temperature; and the effect of age and of weight on basal metabolic rate. Journal of Physiology 180, 239-265.

Hyvarinen, H., Pasanen, S., Hejkura, H., Heinineva, R. \& Laru, H. (1976). Effects of a cold environment on energy-related enzyme activities in the postnatal rat. Growth 40, 41-52.

Karlberg, P., Moore, R. E. \& Oliver, T. K. (1965). Thermogenic and cardiovascular responses of the newborn baby to noradrenaline. Acta Paediatrica Scandinavica 54, 225-238.

Klein, A. H., Oddie, T. H. \& Fisher, D. A. (1980). Iodothyronine kinetic studies in the newborn lamb. Journal of Developmental Physiology 2, 29-35.

Leury, B. J., Bird, A. R., Chandler, K. D. \& Bell, A. W. (1990). Glucose partitioning in the pregnant ewe: effects of undernutrition and exercise. British Journal of Nutrition 64, 449-462.

Lindsay, D. B. \& Ford, E. J. H. (1964). Acetate utilization and the turnover of citric acid-cycle components in pregnant sheep. Biochemical Journal 90, 24-30.

Mellor, D. J. (1983). Nutritional and placental determinants of foetal growth rate in sheep and consequences for the newborn lamb. British Veterinary Journal 139, 307-324.

Mellor, D. J. \& Cockburn, F. (1986). A comparison of energy metabolism in the new-born infant, piglet and lamb. Quarterly Journal of Experimental Physiology 71, 361-379.

Merklin, R. J. (1974). Growth and distribution of human fetal brown fat. Anatomical Record 178, 637-646.

Moragas, A. \& Toran, N. (1983). Perinatal development of brown adipose tissue in man. Biology of the Neonate 43, 80-85.

Mory, G., Bouillaud, F., Combes-George, M. \& Riquier, D. (1984). Noradrenaline controls the concentration of the uncoupling protein in brown adipose tissue. FEBS Letters 166, 393-396.

Mouroux, I., Bertin, R. \& Portet, R. (1990). Thermogenic capacity of brown adipose tissue of developing rats; effects of rearing temperature. Journal of Developmental Physiology 14, 337-342.

Naeye, R. L. (1974). Hypoxemia and the Sudden Infant Death Syndrome. Science 186, 837-838.

Naeye, R. L. (1980). Sudden Infant Death. Scientific American 242, 52-58. 
Polk, D. M., Wu, S. \& Fisher, D. A. (1986). Serum thyroid hormones and tissue 5-monodeiodinase activity in acutely thyroidectomized newborn lambs. American Journal of Physiology 251, E151-E155.

Power, G. G. (1989). Biology of temperature: the mammalian fetus. Joumal of Developmental Physiology 12, 295-304.

Rutter, W., Laird, T. R. \& Broadbent, P. J. (1971). The effects of clipping pregnant ewes at housing and of feeding different basal roughages. Animal Production 13, 329-336.

Rylander, E. (1972). Age dependent reactions of rectal and skin temperature of infants during exposure to cold. Acta Paediatrica Scandinavica 61, 597-605.

Sawa, R., Asakura, H. \& Power, G. G. (1991). Changes in plasma adenosine during simulated birth of fetal sheep. Journal of Applied Physiology 70, 1524-1528.

Silva, J. E. \& Larsen, P. R. (1983). Adrenergic activation of triiodothyronine production in brown adipose tissue. Nature 305, 712-713.

Slee, J. (1979). Mortality and resistance to hypothermia in young lambs. In Biometeorological Survey, vol. 1B, pp. 60-65 [S. W. Tromp and J. J. Bouma, editors]. Philadelphia: Heyden.

Slee, J. \& Simpson, S. P. (1991). Description of the effects of a single gene which inhibits the normal metabolic response of newborn lambs to exogenous noradrenaline. Research in Veterinary Science 51, 34-39.

Smales, O. R. C. \& Kime, R. (1978). Thermoregulation in babies immediately after birth. Archives of Disease in Childhood 53, 58-61.

Stevens, D. \& Alexander, G. (1986). Lipid deposition after hypophysectomy and growth hormone treatment in the sheep fetus. Journal of Developmental Physiology 8, 139-145.

Stevens, D., Alexander, G. \& Bell, A. W. (1990). Effect of prolonged glucose infusion into fetal sheep on body growth, fat deposition and gestation length. Journal of Developmental Physiology 13, $277-281$.

Stott, A. W. \& Slee, J. (1985). The effect of environmental temperature during pregnancy on thermoregulation in the newborn lamb. Animal Production 41, 341-347.

Symonds, M. E., Andrews, D. C. \& Johnson, P. (1989). The control of thermoregulation in the developing lamb during slow wave sleep. Journal of Developmental Physiology 11, 289-298.

Symonds, M. E., Bryant, M. J. \& Lomax, M. A. (1986). The effect of shearing on the energy metabolism of the pregnant ewe. British Journal of Nutrition 56, 635-643.

Symonds, M. E., Bryant, M. J. \& Lomax, M. A. (1988a). Metabolic adaptation during pregnancy in winter-shorn sheep. Journal of Agricultural Science, Cambridge 111, 137-145.

Symonds, M. E., Bryant, M. J. \& Lomax, M. A. (1991). The effect of chronic cold exposure during late pregnancy on brown adipose tissue and thermogenesis in the neonatal lamb. Journal of Physiology 438, $236 \mathrm{P}$.

Symonds, M. E., Bryant, M. J., Shepherd, D. A. L. \& Lomax, M. A. (1988b). Glucose metabolism in shorn and unshorn pregnant sheep. British Journal of Nutrition 60, 249-263.

Thompson, G. E., Bassett, J. M., Samson, D. E. \& Slee, J. (1982). The effect of cold exposure of pregnant sheep on foetal plasma nutrients, hormones and birth weight. British Journal of Nutrition 48, $59-64$.

Tyzbir, R. S. (1984). Altered brown adipose tissue mitochondrial function in neonates born to rats overfed foods of various protein content. Journal of Nutrition 114, 234-237.

Vernon, R. G. (1986). The growth and metabolism of adipocytes. In Control and Manipulation of Animal Growth, pp. 67-83 [P. J. Buttery, D. B. Lindsay and N. B. Haynes, editors]. London: Butterworths.

Vernon, R. G., Robertson, J. P., Clegg, R. A. \& Flint, D. J. (1981). Aspects of adipose tissue metabolism in foetal lambs. Biochemical Journal 196, 819-824.

Wu, S. Y., Merryfield, M. L., Polk, D. H. \& Fisher, D. A. (1990). Two pathways for thyroxine 5 'monodeiodination in brown adipose tissue in fetal sheep. Endocrinology 126, 1950-1958. 